\title{
磁気駆動アーク運動方程式の無次元化解析
}

\author{
秋保 良太 ${ }^{* 1}$, 武田 紘一²，杉本 尚哉*3
}

\section{Non-dimensional analysis on the momentum equation of the magnetically driven arc}

\author{
Ryota AKIHO $^{* 1}$, Koichi TAKEDA ${ }^{* 2}$ and Masaya SUGIMOTO*3 \\ ${ }^{* 1, * 2, * 3}$ Faculty of Systems Science and Technology, Akita Prefectural University, \\ 84-4 Tsuchiya-Ebinokuchi, Yurihonjo-shi, Akita 015-0055, Japan
}

\section{Received 24 February 2014}

\begin{abstract}
Arc behavior under an alternating magnetic field to the arc is theoretically investigated. It is known that the arc profiles are influenced by various operating parameters such as an imposed magnetic flux density, an arc current, a flow rate to the plasma gas and so on. Therefore theoretical analysis on the arc is complicated. In the present work, the authors investigated a new approach to understand the arc behavior driven by the alternating magnetic field. A characteristic time and a characteristic length were defined. Using these characteristic time and length, the fundamental equations which governed the arc behavior were rewritten into the non-dimensional forms. Appropriate choices of these characteristic values made it possible to eliminate the influences of the various operating parameters from the non-dimensional equations. As the result, numerical analyses became very easy. Non-dimensional arc profiles obtained from the non-dimensional differential equations were rearranged into real arc profiles by the simple inverse conversions from the non-dimensional values to the real dimensional ones. Influences of the operating parameters appear again in the arc behavior through the inverse conversion processes.
\end{abstract}

Key words : Alternating magnetic field, Electromagnetic force, Transferred arc, Non-dimensional analysis

\section{1. 緒言}

アークは，熱効率の高い熱源として金属の加熱，溶断，溶接等の手段として工業的に幅広く利用されている. アークの出力は通電量の調節によって容易に制御することが可能であり，動作ガスを変化させることで雰囲気制 御も可能である。しかし，アークの磁気ピンチ効果により熱流は狭い範囲に集中するため，広い範囲の加熱には 不向きである.そこでアークによる加熱面積を拡大する試みが過去にいくつかなされてきた (Arata, et al., 1972, Harry and Goodwin, 1978, Solonenko and Fedorchenko, 1990, Takeda, 1990, Tanaka, et al., 2005, Toh, et al., 2005). 筆者ら は，アークに直交する交流磁界を印加することでアークを高速で往復運動をさせ， 2 次元的に広がったアーク熱 源を得る，磁気駆動アークの研究に取り組んで来た (Yamamoto, 2010, Yamamoto, et al., 2007, 秋保他，2013). 磁気 駆動アークは従来のアークの特徵に加えて以下の利点を有する.

（1）印加磁界の強度を調節することでアーク熱源の加熱幅を容易に制御できる.

No.14-00106 [DOI: 10.1299/transjsme.2014fe0257]

*1 正員，秋田県立大学大学院 システム科学技術研究科（†015-0055＼cjkstart秋田県由利本荘市土谷字海老ノ口 84-4)

*2 秋田県立大学 システム科学技術学部

*3 正員, 秋田県立大学 システム科学技術学部

E-mail of corresponding author: M14A001@akita-pu.ac.jp 
（2）交流磁界の時間変化波形を変えることによって 2 次元的に広がったアーク中の熱流分布を制御できる.

図 1 に様々な磁気駆動アークの画像を示す.アークは一般に, 高エネルギ一密度熱源として図 1 (a) に示すよ うに細いビーム形状になる，アークに直交する交流磁界を作用させると，正弦波励磁電流の場合は図 1 (b)，矩 形波励磁電流の場合は図 1 （c）のようにアークが変形する. 正弦波励磁電流が供給された場合は，拡大した加熱 面が得られる．矩形波励磁電流が印加された場合は，熱流は拡大した熱源幅の両端に集中し，異なる二箇所を同 時に加熱できる. 2 次元に往復運動させる磁気駆動アーク技術は，鉄鋼業におけるスラブ鋳片の表層を溶融し表 面改質する応用 (Yamamoto, 2010) や金属材料の表面を種々のパターンで焼入れ熱処理を行う応用 (秋保他, 2013) への展開が試みられている.

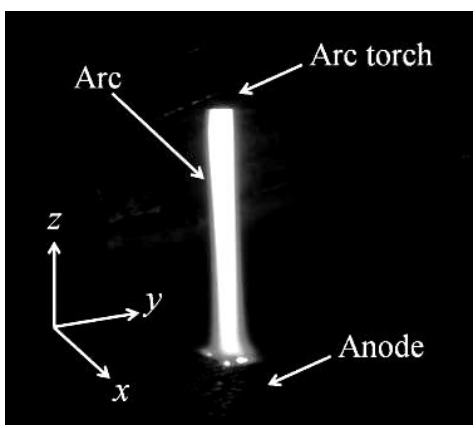

(a) No magnetic field

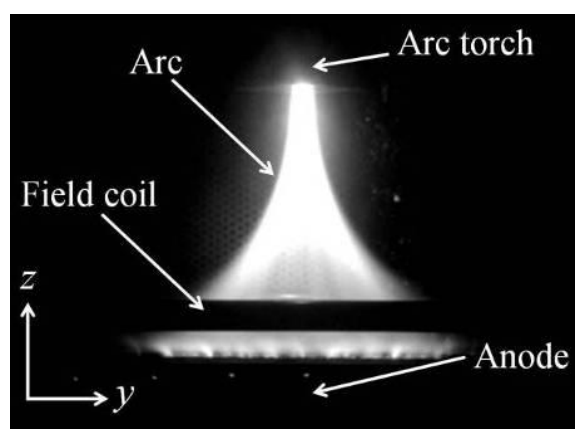

(b) Orthogonal alternating magnetic field (sine wave form)

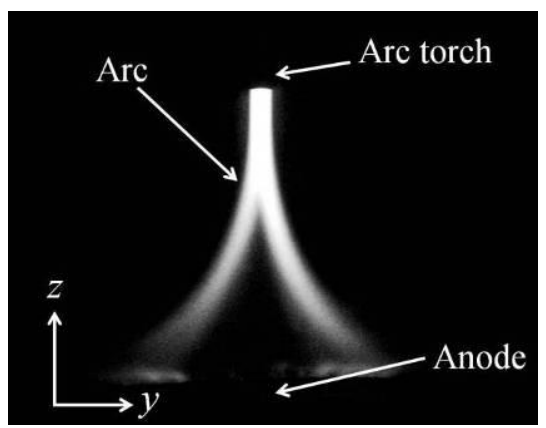

(c) Orthogonal alternating magnetic field (rectangular wave form)

Fig. 1 Plasma arc profiles for various types of magnetic field: Under no external magnetic field, arc is straight as shown in (a). When the alternating magnetic field with sine wave form is imposed, expanded arc is obtained as shown in (b). And if the wave form is rectangular, the arc as shown in (c) is observed.

近年，筆者らはアークに作用させる交流磁界を，アークと直交させるだけでなく斜交させる場合についても検 討し，アーク形状が図 2 に示すように 3 次元的に広がることを明らかにした (Akiho, et al., 2012).

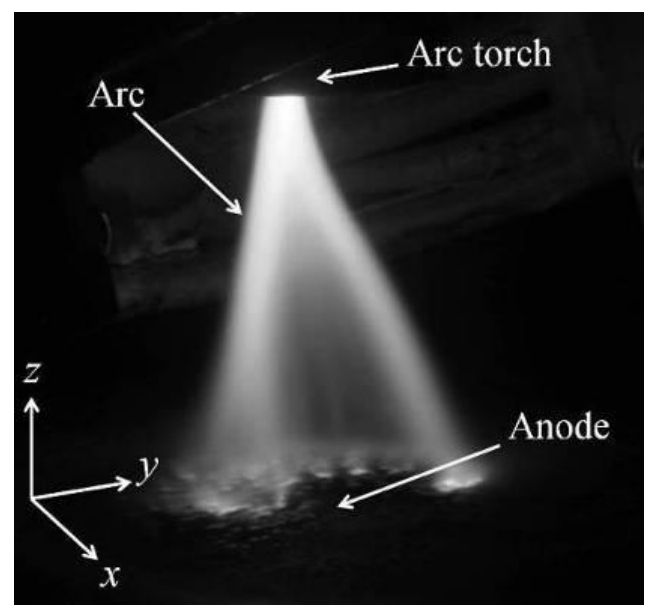

Fig. 2 Plasma arc profile for oblique alternating magnetic field: The oscillating arc moves three-dimensionally.

アークに直交する磁界を作用させた場合，磁気駆動アークの挙動は，アーク電流值や電極間距離，動作ガス流 量, トーチノズル径, 励磁電流值など様々なパラメータの関数となり, 数值解析は煩雑である. そのため理論的 にその挙動を推定することは容易ではない，まして，斜交磁界とした場合には，これらのパラメータに加え，印 加磁界とアークとの角度が影響することも考慮せねばならない. アークの運動方程式の数值解析はさらに複雑と なり，アーク挙動の予測も困難になる． 
本研究では外部交流磁界中の磁気駆動アーク挙動を理論検討寸る際，時間と長さに関し，それぞれ特性的時間 と特性的長さを導入して, 時間及び位置座標を無次元化し,アークの運動を記述する基礎方程式を無次元化した. これにより，アークの振る舞いの見通しが良くなり，数值解析も容易になることを明らかにした．第 2 章では理 論検討するモデルとアークの運動を記述する従来座標空間での基礎方程式について述べる. 第 3 章では特性的時 間，および特性的長さの導入と，無次元化された時間・空間での基礎方程式とその特徵について述べる. 第 4 章 では無次元化方程式から導かれる無次元化された時間及び座標でのアークの振る舞いについて述べる. 第 5 章で は無次元空間で求められたアークの挙動を, 実空間での挙動に変換し, 実空間でのアークの振る舞いについて述 べる. 第 6 章は結言である.

\section{2. 磁気駆動アークの運動を支配する基礎方程式}

図 3 に理論討論するモデルの概念図を示す，座標系の原点をプラズマトーチ開口部の端にとり，陽極からプラ ズマトーチに向から方向を $z$ 軸正の方向とする. 陽極位置は $z=z^{*}[\mathrm{~m}]$ と寸る. 図より明らかなように，このモ デルでは $z^{*}[\mathrm{~m}]$ は負の量である. 陰極はプラズマトーチ内にあり, 陽極と陰極の間に移行型アークが発生する. アークに印加する交流磁界 $\boldsymbol{B}$ [T] が $z-x$ 平面内にあるように $x$ 軸を設定し, 磁界方向と $z$ 軸のなす角度を $\theta[\mathrm{rad}]$ と する. また，右手座標系になるように $y$ 軸方向を定義し， $x$ 軸，y軸それぞれの正の方向は図に示寸矢印の方向で ある. 磁束密度は空間的に均一で次式で表わされるものとする.

$$
\begin{aligned}
& \boldsymbol{B}=\left(B_{x}, 0, B_{z}\right), \\
& B_{x}^{2}+B_{z}^{2}=B^{2}, \\
& B_{x}=B \sin \theta, B_{z}=B \cos \theta .
\end{aligned}
$$

交流磁界を考えているので， $B[\mathrm{~T}]$ は振幅最大幅 $B_{0}[\mathrm{~T}]$ と最小值 $-B_{0}[\mathrm{~T}]$ の間を変化し,

$$
-B_{0} \leq B \leq B_{0} .
$$

$\theta[\mathrm{rad}]$ は 0 から $\pi / 2$ までの值を持ち, $\theta=\pi / 2[\mathrm{rad}]$ のときは直交磁界の場合となる.

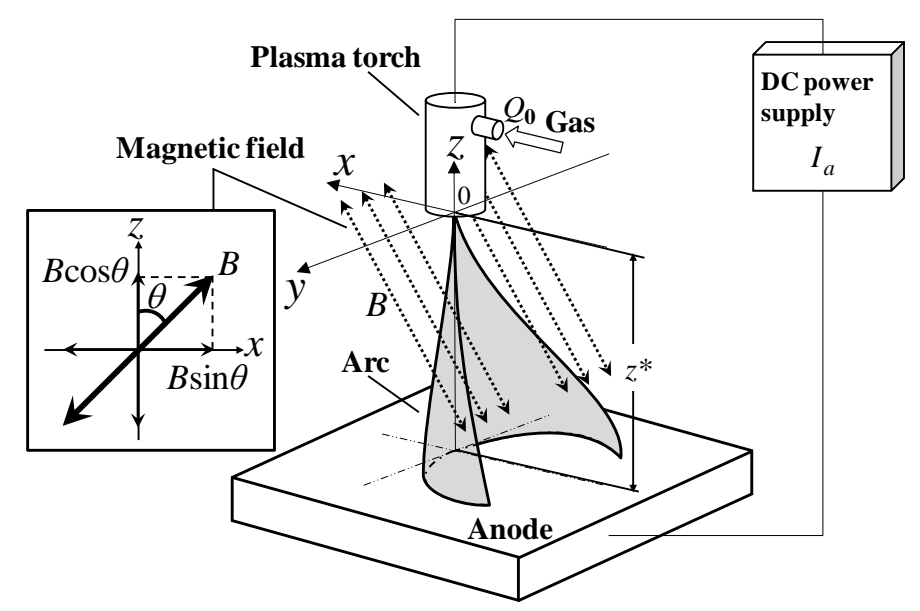

Fig. 3 Schematic arrangement of the magnetically driven arc used in the theoretical consideration. The alternating magnetic field is imposed obliquely at the angle of $\theta$ [rad].

理論解析で用いられる物理量を示す記号を以下の表にまとめて示す.

Table 1 Nomenclatures.

\begin{tabular}{ll}
\hline $\boldsymbol{B}$ & Vector quantity of magnetic flux density [T] \\
$B$ & Magnetic flux density [T] \\
$B_{0}$ & Amplitude of magnetic flux density [T]
\end{tabular}




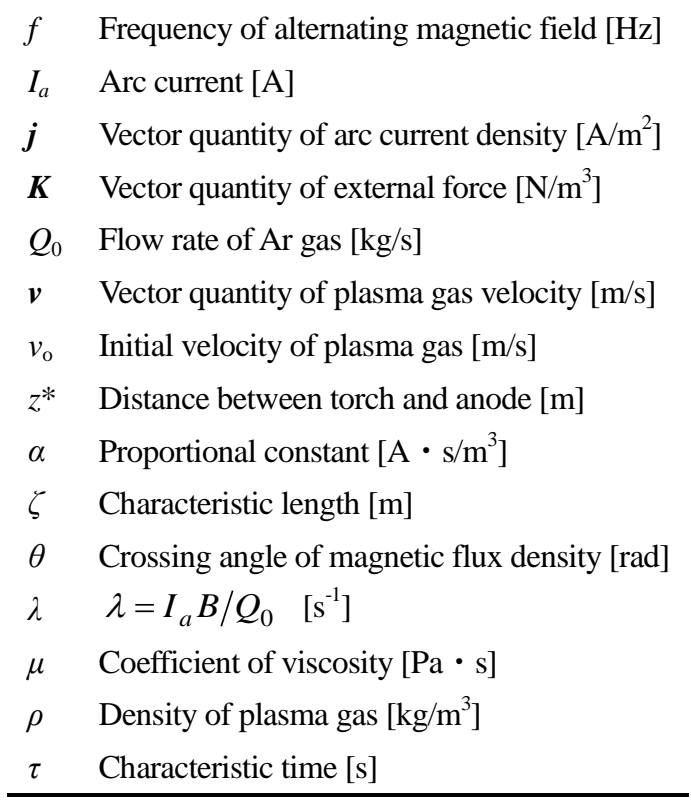

アーク電流は導電性ガス中しか流れられないので，トーチノズルから出発したプラズマガスが陽極に到達する までの運動軌跡と陽極・トーチ間のアーク形状は一致する。したがって, 磁界中でのアーク形状の変化は, 磁界 中のプラズマガスの運動軌跡から明らかになるはずというのが，磁気駆動アーク挙動の理論解析の基本的考え方 である，プラズマガスの運動は，次の連続の式と運動方程式に従う.

$$
\begin{aligned}
& \frac{\partial \rho}{\partial t}+\nabla \cdot(\rho \boldsymbol{v})=0 \\
& \rho \frac{d \boldsymbol{v}}{d t}=\boldsymbol{K}-\nabla p+\mu \nabla^{2} \boldsymbol{v}+\frac{\mu}{3} \nabla(\nabla \cdot \boldsymbol{v})
\end{aligned}
$$

ここで，式（3)，（4）を扱うに際し，以下の仮定を用いて式を簡略化している.

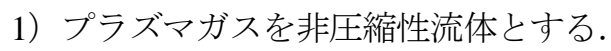

2）プラズマガスの圧力は一定である.

3）プラズマガスの粘性は無視できるほど小さい.

4）プラズマガスに作用する外力は電磁力 $\boldsymbol{K}=\boldsymbol{j} \times \boldsymbol{B}$ のみとする.

5）アーク電流密度ベクトル $\boldsymbol{j}$ とプラズマガス速度ベクトル $\boldsymbol{v}$ の間には $\boldsymbol{j}=-\alpha \boldsymbol{v}$ の関係が成り立つ.

この 5）の仮定は上に述べたプラズマガスの運動軌跡とアーク形状が一致するはずであるとの考えに基づいたも のである.アーク電流とプラズマガスの速度ベクトルの関係がマイナス符号で結ばれているのは，アーク電流は 陽極からプラズマトーチに向かい流れるのに対し，プラズマガスはプラズマトーチから陽極に向かうので，両者 のベクトル方向が逆になっているためである.ここで $\alpha$ は正の定数である. 以上の仮定に加え, さらに交流磁界 の周波数に関して次の 6) に示す仮定を考える.

6）交流磁界の周波数 $f$ は $f \ll\left|v_{\mathrm{o}} / z^{*}\right|$ を満たす範囲とする.

この仮定は，アークに作用する交流磁界の時間変化が十分に遅く，プラズマガスがプラズマトーチから出発して 陽極に至るまでに，磁界強度がほとんど変化しないと考えて良いことを意味している．商用周波数程度の交流磁 界ではこの仮定は満足される．1）から5）の仮定は，先行研究より理論解析結果と実験結果は合致しており，妥 当な仮定であることが確かめられている (Yamamoto, 2010).

以上の条件を用いることにより，式（4）のベクトル微分方程式は，3つのスカラー運動方程式に分解され，最 終的に式（5）から式（7）に示す３階常微分方程式に書き換えられる. 詳細な導出過程は文献 (Akiho, et al., 2012) に説明されているので, ここでは結果のみを示す.

$$
x \text { 成分 : } \frac{d^{3} x}{d t^{3}}+\lambda^{2} \frac{d x}{d t}-\lambda^{2} v_{0} \sin \theta \cos \theta=0
$$


$\begin{array}{ll}y \text { 成分： } & \frac{d^{3} y}{d t^{3}}+\lambda^{2} \frac{d y}{d t}=0 \\ z \text { 成分： } & \frac{d^{3} z}{d t^{3}}+\lambda^{2} \frac{d z}{d t}-\lambda^{2} v_{0} \cos ^{2} \theta=0\end{array}$

ここで入はアーク電流 $I_{a}$, 磁束密度 $B$ およびガス流量 $Q_{0}$ により次式で定義される.

$$
\lambda=\frac{I_{a} B}{Q_{0}}
$$

時刻 $t=0$ でプラズマトーチを出発したプラズマガスが, 時刻 $t=t^{*}$ で存在す位置座標を $x\left(t^{*}\right), y\left(t^{*}\right), z\left(t^{*}\right)$ とすれば, それぞれの座標位置は式 (5)，（6）および（7）の3 階常微分方程式を解いて与えられる.アークに作用する磁界 の強度と方向，アーク電流，プラズマガス流量が与えられれば，そのときの $\lambda$ が決まり，その $\lambda に$ 対応したプラ

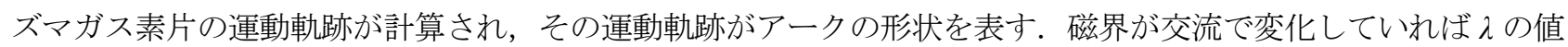
が変わる. 交流磁界中でのアークの振る舞いを知るためには, 式（9）を満足する様々な $\lambda に$ 対して別々の微分方 程式があり，別々に解を求めなければならない.

$$
-\frac{I_{a} B_{0}}{Q_{0}} \leq \lambda \leq \frac{I_{a} B_{0}}{Q_{0}}
$$

3 階常微分方程式を解くには, 3 つの初期条件が与えられなければならない. 図 3 に示されるモデルでの初期条 件は式（10）で与えられる.

$$
\begin{aligned}
& (x, y, z)_{t=0}=(0,0,0) \\
& \left(\frac{d x}{d t}, \frac{d y}{d t}, \frac{d z}{d t}\right)_{t=0}=\left(0,0, v_{0}\right) \\
& \left(\frac{d^{2} x}{d t^{2}}, \frac{d^{2} y}{d t^{2}}, \frac{d^{2} z}{d t^{2}}\right)_{t=0}=\left(0,-\lambda v_{0} \sin \theta, 0\right)
\end{aligned}
$$

著者らは様々な $\theta$ の交流磁界中でのアークの挙動について数值計算を行っており, 文献 (Akiho, et al., 2012) に その結果を報告している. 数值解析結果の一例をとして, $\theta=\pi / 6$ の場合のアーク形状に磁界による変化の様子を 図 4 に示寸.

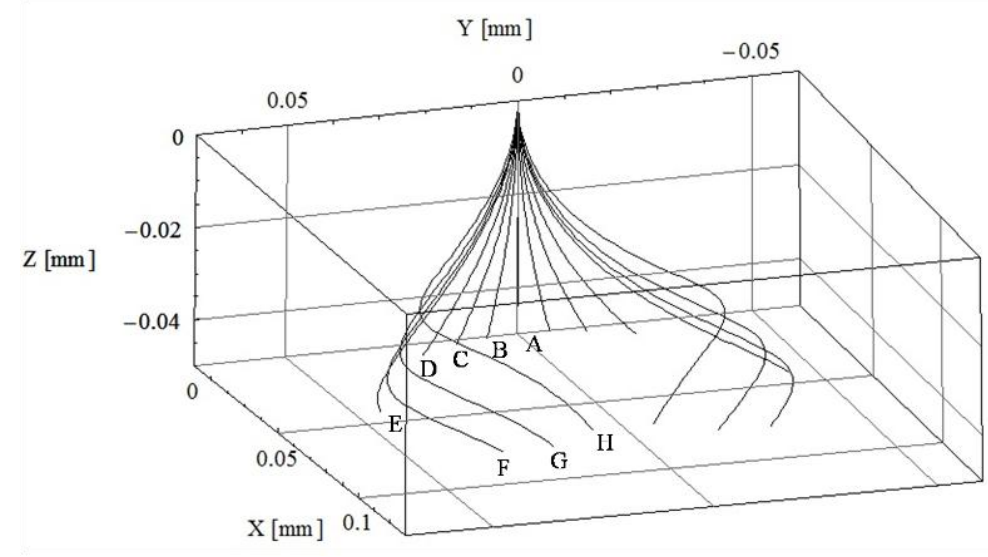

Fig. 4 Numerical results of magnetically driven arc behaviour at $\theta=\pi / 6^{(10)}$. The calculation was carried out under the following conditions; $I_{a}=90 \mathrm{~A}, Q_{0}=3.0 \times 10^{-4} \mathrm{~kg} / \mathrm{s}, v_{\mathrm{o}}=-80 \mathrm{~m} / \mathrm{s}, z^{*}=-0.05 \mathrm{~m}$. The anode root of the arc moves from A to $\mathrm{H}$ with the increase of magnetic flux density from 0 to $20 \mathrm{mT}$. 


\section{3. 運動方程式の無次元化}

アークに対して任意の角度で交流磁界を印加する場合の, 磁気駆動アークの挙動を本質的に理解するために,

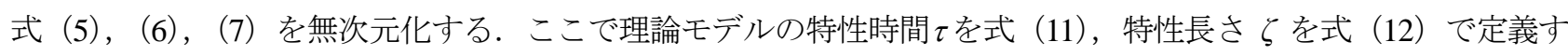
る.

$$
\begin{aligned}
& \tau=-\frac{1}{\lambda} \\
& \zeta=v_{0} \tau=-\frac{v_{0}}{\lambda}
\end{aligned}
$$

定義された特性時間, 特性長さを用いて, 変数 $\{x(t), y(t), z(t)\}$ を次のように無次元化する.

$$
X=\frac{x}{\zeta}, \quad Y=\frac{y}{\zeta}, \quad Z=\frac{z}{\zeta}, \quad T=\frac{t}{\tau}
$$

式（13）の関係加

$$
\begin{aligned}
& \frac{d x}{d t}=\left(\frac{d x}{d T}\right)\left(\frac{d T}{d t}\right)=\frac{\zeta}{\tau} \frac{d X}{d T} \\
& \frac{d^{3} x}{d t^{3}}=\left(\frac{d^{2}}{d t^{2}}\right)\left\{\left(\frac{d x}{d T}\right)\left(\frac{d T}{d t}\right)\right\}=\frac{\zeta}{\tau^{3}} \frac{d^{3} X}{d T^{3}}
\end{aligned}
$$

の関係が得られる.これらを式（5）に代入すると次の無次元化方程式が得られる.

$$
X \text { 成分： } \quad \frac{d^{3} X}{d T^{3}}+\frac{d X}{d T}-\sin \theta \cos \theta=0
$$

同様に $Y$ 成分, $Z$ 成分についても以下の無次元化方程式に書き換えられる.

$Y$ 成分 : $\quad \frac{d^{3} Y}{d T^{3}}+\frac{d Y}{d T}=0$

$Z$ 成分： $\quad \frac{d^{3} Z}{d T^{3}}+\frac{d Z}{d T}-\cos ^{2} \theta=0$

式 (15), 式 (16), 式 (17) から明らかなように, 無次元時間 $T$ の関数としてのプラズマガスの無次元座標上の 位置を表す $\{X(T), Y(T), Z(T)\}$ は, 印加磁界の角度 $\theta$ のみに関係する微分方程式から求まるので, 印加磁界 $B$ やア 一ク電流 $I_{a}$ ，プラズマガス流量 $Q_{0}$ およびプラズマガス初速度 $v_{0}$ の值に無関係である．なお式（10）で与えられ ていた初期条件も, 式（18）のように印加磁界 $B$, アーク電流 $I_{a}$, プラズマガス流量 $Q_{0}$ およびプラズマガス初速 度 $v_{0}$ の值に無関係な形になる。

$$
\begin{aligned}
& \left.X\right|_{T=0}=0,\left.\quad \frac{d X}{d T}\right|_{T=0}=0,\left.\quad \frac{d^{2} X}{d T^{2}}\right|_{T=0}=0, \\
& \left.Y\right|_{T=0}=0,\left.\quad \frac{d Y}{d T}\right|_{T=0}=0,\left.\quad \frac{d^{2} Y}{d T^{2}}\right|_{T=0}=\sin \theta, \\
& \left.Z\right|_{T=0}=0,\left.\quad \frac{d Z}{d T}\right|_{T=0}=1,\left.\quad \frac{d^{2} Z}{d T^{2}}\right|_{T=0}=0
\end{aligned}
$$

すなわち，無次元化された空間でのプラズマガスの軌跡（アーク形状）は磁界ベクトルの角度を示す $\theta$ にの関 係する.

\section{4. 無次元化された運動方程式の数值解析結果}

無次元化された座標空間でのプラズマガスの軌跡を数值解析した結果を以下に示す．数值解析は数值計算ソフ 卜「MATHEMATICA (Wolfram, 1998)」を用いて行った。無次元微分方程式（15）から（17）までの解を求める にあたり，無次元時間 $T$ の方向に正負があることに留意せ㸚ばならない，第2 章では，式（5）から式（7）まで の無次元化されていない微分方程式を解いて, 時間とともに変化する $x(t), y(t), z(t)$ を求め, 時間 $t=0[\mathrm{~s}]$ から 出発するプラズマガスの軌跡を調べている．この場合， $t$ を正の方向に変化させることが暗黙の了解となってい 
る. しかしながら，無次元時間 $T$ と実時間 $t$ との間には， $T=-\lambda t$ の関係があるため, $t$ が正に変化することを前 提にしても, $\lambda$ の正負により $T$ の変化の方向は異なり, $\lambda>0$ であれば $T$ の変化の方向は負, $\lambda<0$ であれば $T$ の変 化の方向は正となる． $\lambda$ と無次元時間 $T$ の符号が逆転することに注意せ齐ばならない.

$\theta=\pi / 2, \pi / 2>\theta>\pi / 4$ および $\theta \leqq \pi / 4$ の場合の 3 つのケースについて, 図 5 および図 6 にそれぞれ数值計算した 結果を図示する. 図 5 はアークに対し磁界が直交している場合に相当しており, プラズマガスの運動軌跡は，Y-Z 平面上にあり, 中心が $Y=1, Z=0$ にある半径 1 の円となっている. $\lambda$ が正の場合のプラズマガスの運動は, $T=0$ で 原点 $(X=0, Y=0, Z=0)$ から出発し, 無次元化時間の経過とともに時計まわりに円周上を動く. $\lambda$ が負の場合も

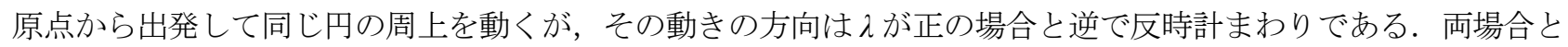
も運動の軌跡は円弧状である

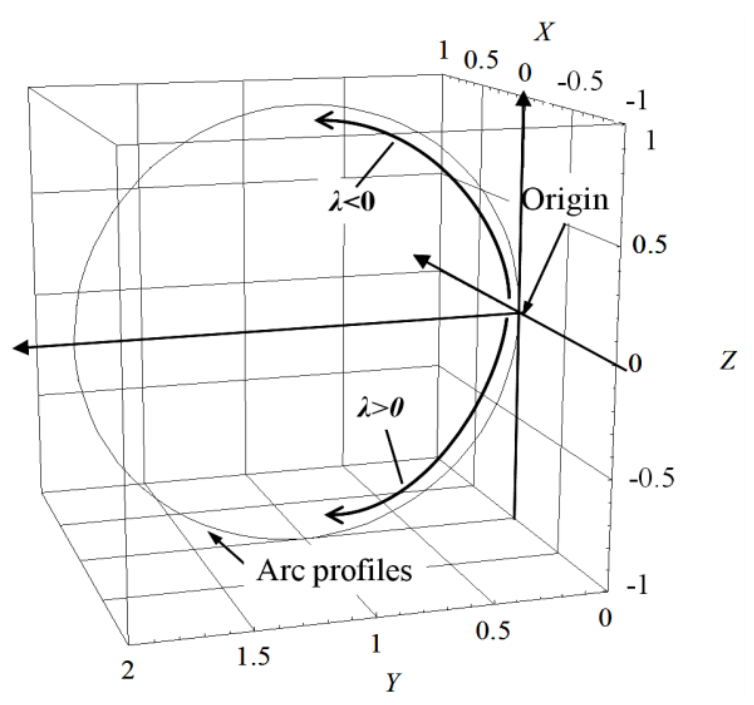

Fig. 5 Numerical result for $\theta=\pi / 2$. The plasma gas moves on the circle, the radius of which equals 1 . The direction of the movement depends on $\lambda$; if $\lambda>0$, it moves clockwise and if $\lambda<0$, counter-clockwise.

図 6 はアークに対して斜め方向に磁界が印加する場合に相当し，(a)は $\pi / 2>\theta>\pi / 4$ の場合のプラズマガスの運 動を描いたものである. 代表例として, $\theta=\pi / 3$ の場合を取り上げて運動の軌跡を示す．磁界の交流変化を考えれ ば， $\theta=\pi / 2$ の場合と同様 $\lambda$ が正の場合の軌跡と， $\lambda$ が負の場合で別々に軌跡を求め，全体の挙動は表現する. 煩 雑さを避けるため, 以降の数值解析結果では $\lambda$ の正の場合についてのみ考え, $\lambda$ の負の場合の軌跡は省く. 現象 の対称性を考慮すれば， $\lambda$ が負の場合の軌跡は $\lambda$ が正の場合の軌跡の軸対称であり，対称軸は原点を通る $Y$ 軸で ある. 無次元座標上でのプラズマガスの軌跡は, 円運動が磁界ベクトルの方向に引き伸ばされた形状となる.

図 6(b)は $\theta \leqq \pi / 4$ の場合を示すものであるが，代表例として $\theta=\pi / 6$ の值を用いて計算している. この場合も， 無次元座標上でのプラズマガスの軌跡は, 円運動が磁界ベクトルの方向に引き伸ばされる. 


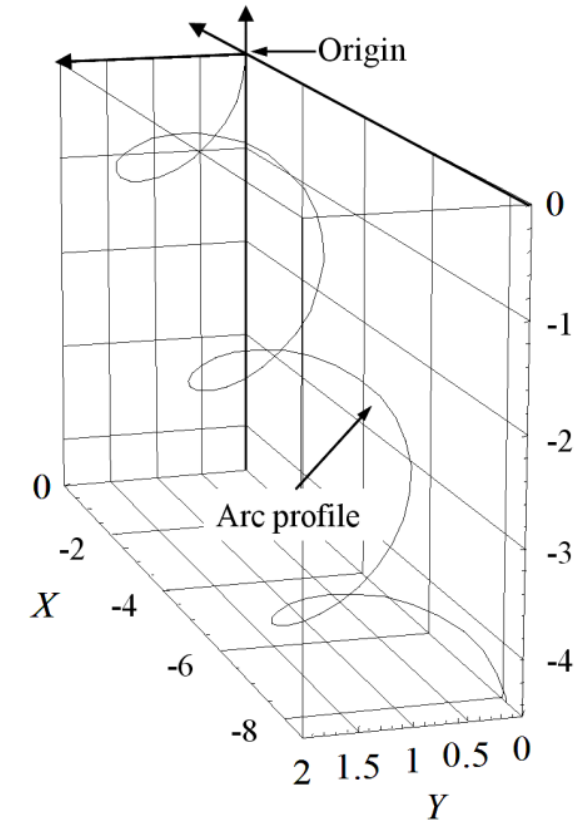

(a) $\theta=\pi / 3$.

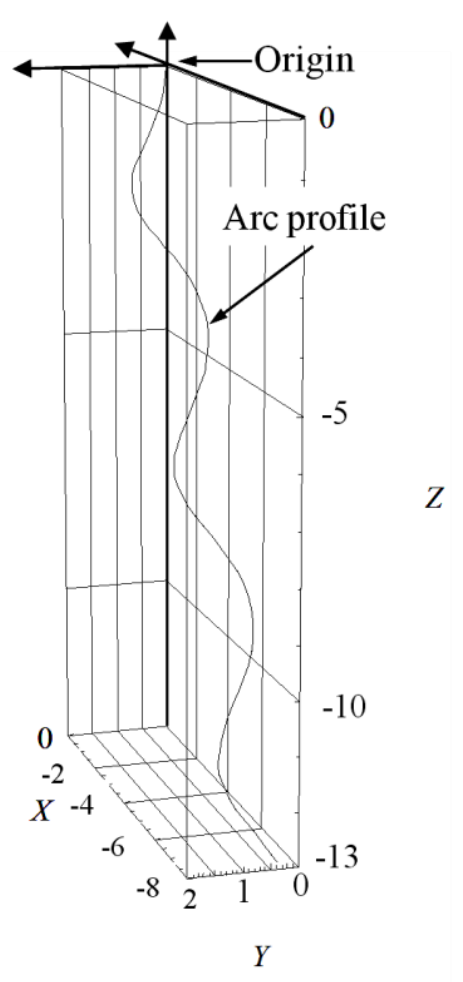

(b) $\theta=\pi / 6$.

Fig. 6 Numerical results of the plasma gas movement for $\theta=\pi / 3$ (a) and for $\theta=\pi / 6$ (b). The plasma gas moves along a line of solenoid. Its radius decreases with the decrease of $\theta$.

\section{5.＼cjkstart無次元空間でのアーク挙動から実空間でのアーク挙動への変換および討論}

陽極面の位置を $z^{*}$ （図 3 のモデルでは $z^{*}$ は負の值）とし，アーク電流，プラズマガス流量がそれぞれ $I_{a} ， Q_{0}$ （両者はともに正の值），プラズマガスがプラズマトーチより吹き出す速度が $v_{\mathrm{o}}(z$ 軸負の方向に吹き出すので $v_{\mathrm{o}}$ は負の值) で，アークに作用する磁界 $B$ が $-B_{0}$ と $B_{0}$ の間で交流変化するとき, アークの形状がどのように変化 するのかを, 無次元方程式から導かれた解をもとに考える. 無次元方程式の解を, もとの時刻 $t$ における $x, y, z$ 座標に戻すには，無次元変数と現実の有次元変数に式（13）の関係を用いてもとに戻せばよい.

$$
t=-\frac{T}{\lambda}, \quad x=-\frac{v_{0}}{\lambda} X, \quad y=-\frac{v_{0}}{\lambda} Y, \quad z=-\frac{v_{0}}{\lambda} Z
$$

座標変換にあたり, 磁界の傾き $\theta$ の值によりアーク挙動に異なる特徵が現れるので, 前章で解いた $\theta=\pi / 2$ およ び $\pi / 2>\theta>\pi / 4, \pi / 4 \geqq \theta$ のつの場合に分けてそれぞれの結果を示す.

\section{$5 \cdot 1 \quad$ 磁界がアークと直交する $(\theta=\pi / 2)$ 場合}

この場合, 無次元化空間でのプラズマガスの運動軌跡は図 5 に示寸通りである. $\lambda$ が正のときは, $T=0$ で原 点を出発したプラズマガスは, 無次元化時間 $T$ の変化とともに図に示される円の上を時計まわりに動いていく. この運動は $Y-Z$ 平面上のみでの動きとなり, 常に $X=0$ である.したがって, 実空間での軌跡の $x$ 座標は $x=0$ で ある. 無次元空間で円周上を動く軌跡が $\lambda$ の変化に伴い，実空間でどのような軌跡になるのか，その変化の様子 を図 7 に示している. 図中 $z=z^{*} の x-y$ 平面は陽極面を示寸．無次元空間で表される円形の軌跡は，式（19）の 変換をして, 実空間上に移してもやはり円形であるが, その半径は $\lambda$ の值に応じて変わる. $\lambda=0$ (磁界強度 $B=0)$ のときは円の半径が無限大となるので, その軌跡は図 7 の実線 $\mathrm{A}$ のように $z$ 軸に平行な直線形状である. また $\lambda$ が増加するとともに，プラズマガスの円軌跡の半径は小さくなり，図から明らかなように入が大きくなりすぎる とプラズマガスの軌跡は陽極面と交わらなくなる．プラズマガスが陽極面と交わらないということは，アークが 
陽極と接しないことになる.アークが陽極に接しないとアーク電流の流れる回路が無くなるので，現実にこのよ うなアークは存在できない.

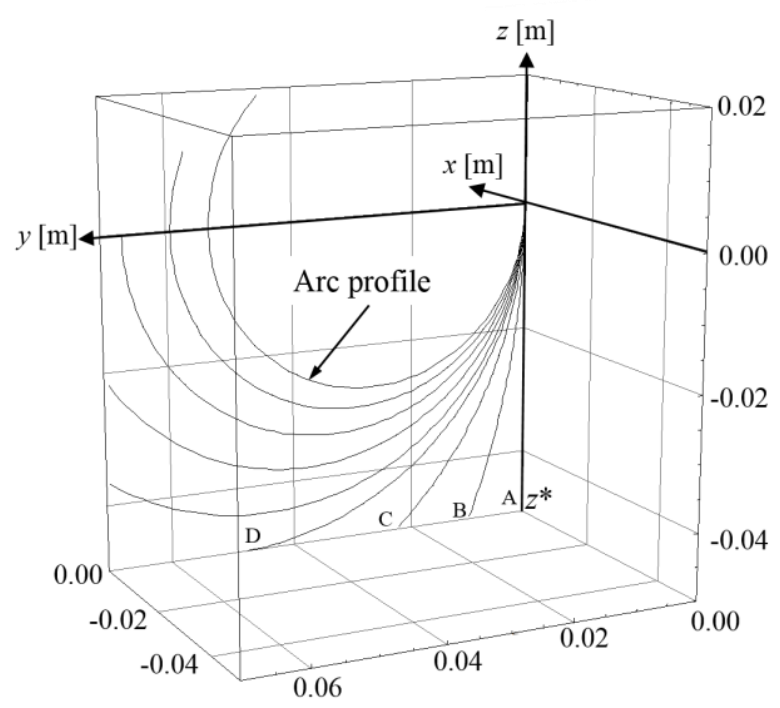

Fig. 7 Arc profiles for various magnetic flux densities $(\lambda>0)$ converted from non-dimensional co-ordinates system $(X, Y, Z)$ to real system $(x, y, z)$. Magnetic field is imposed at the angle of $\theta=\pi / 2$. The curvature of the arc profile is reduced with the increase in $\lambda$.

次に入が負に変化する場合について考える. $\lambda$ が負であるので式（13）から，無次元化された $T$ は正の量とな る. このため, 無次元化された微分方程式は無次元化時間を正の方向に変化させて解を求めなければならない. この場合，図 5 では $T=0$ で原点を出発して，無次元時間の経過とともに，円周上を反時計まわりに動く軌跡と なる. 図 5 から明らかなように, 無次元時間 $T$ でのプラズマガスが存在する座標位置 $Z(T)$ は正, $Y(T)$ は正であ る. 式 $(13)$ に従い無次元空間での $Y(T)$ および $Z(T)$ を実空間に変換すると, $\lambda$ が負, $v_{0}$ も負であるので, $y(t)$, $z(t)$ ともに負の值となる. したがって, $\lambda$ の変化に応じたプラズマガスの軌跡の形状の変化は図 8 に示すように なる.

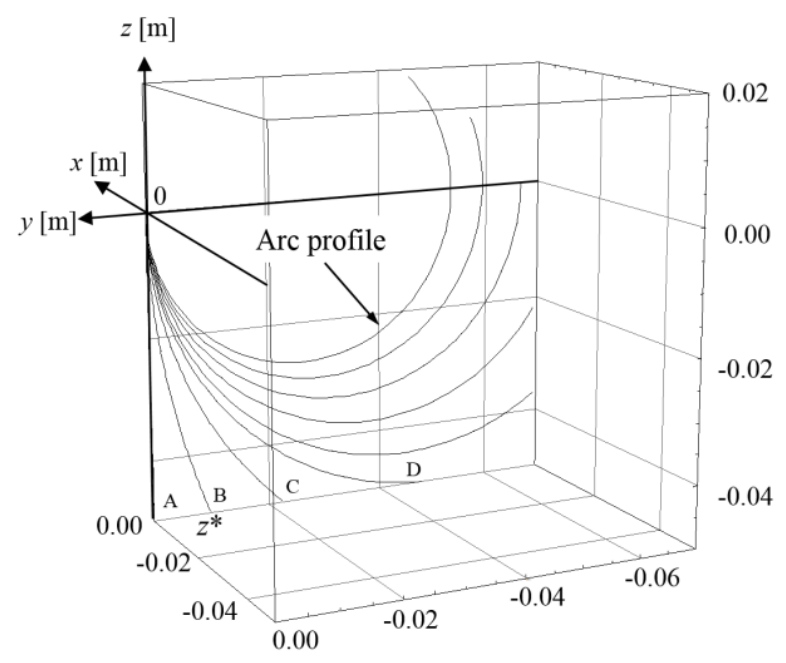

Fig. 8 Arc profiles for several magnetic flux densities $(\lambda<0)$.

磁界が交流で正負の振幅の間を変化すると, 正負の磁界変動に対応した全体のアークの変動は図 9 のようになる. 


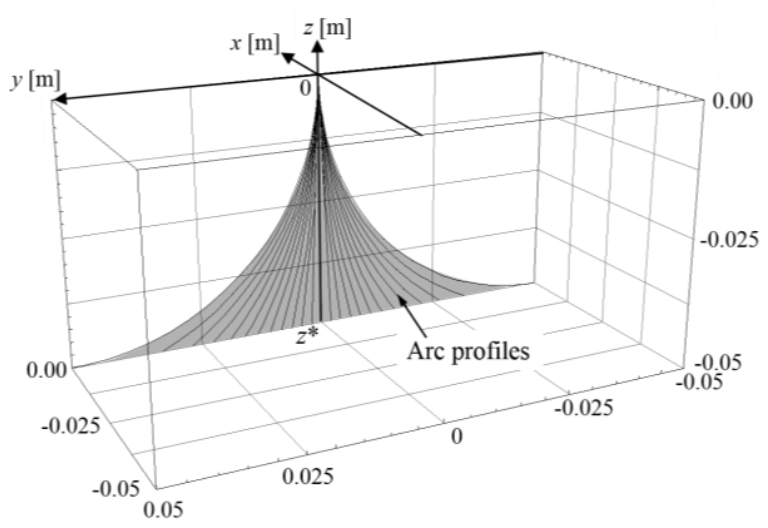

Fig. 9 Arc profile in orthogonal alternating magnetic field. The arc oscillates two dimensionally on the $y-z$ plane.

以上のことから $\theta=\pi / 2$ のときの磁界変化に対するアークの挙動には，次のような特徽があることがわかる.

(1) アークは $y-z$ 平面を動く.

（2）アークの運動振幅は磁束密度が大きくなるほど大きくなる.

（3）交流磁界の振幅強度を大きくしてもアークの往復運動振幅には上限がある.

（4）アーク振幅の上限を決める磁束密度以上に磁界を大きくするとアークは不安定になる.

\section{$5 \cdot 2$ 磁界とアークが $\pi / 2>\theta>\pi / 4$ で斜交する場合}

この場合も $\theta=\pi / 2$ と同様な逆変換を図 6(a)に示される軌跡に対して行う. 無次元空間での軌跡を，様々な $\lambda の$ 值に対して実空間の軌跡に変換した結果を図 10 に示す. $z=z^{*}$ 面は陽極面である. $\lambda$ が小さい範囲では, プラズ マガス軌跡（アーク形状）は常に下方へ向かう．入がある值を超えると，プラズマガス軌跡（アーク形状）は陽 極と交わる前に, いったん陽極から離れ $z$ 軸正の方向に向かい, その後下降に転じて陽極面と交差する形を描く. また，陽極面とプラズマガス軌跡（アーク形状）との交点はアークの陽極点であり，入が小さい場合，アークの 陽極点は $\lambda$ の増加（あるいは磁界強度の増加）とともに $\mathrm{A} \rightarrow \mathrm{B} \rightarrow \mathrm{C} \rightarrow \mathrm{D}$ と連続的に動き，ある值の $\lambda$ （磁界強度） になった途端，D'の位置に不連続に飛ぶ．その後はまた $\lambda$ (磁界強度) の増加とともに $\mathrm{D}^{\prime} \rightarrow \mathrm{E} \rightarrow \mathrm{F} \rightarrow \mathrm{G}$ というよう に連続的に移動する.

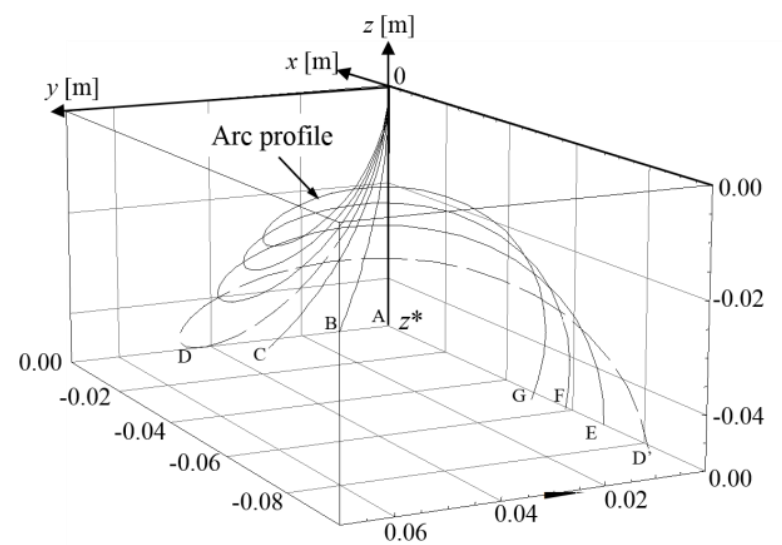

Fig. 10 Arc profiles in oblique magnetic fields $(\theta=\pi / 3)$. The anode root of the $\operatorname{arc}$ moves from $\mathrm{A} \rightarrow \mathrm{B} \rightarrow \mathrm{C} \rightarrow \cdots$ and to $\mathrm{G}$ with the increase of $\lambda$. If $\lambda$ exceeds a certain critical value, anode root jumps discretely as shown from D to D'.

$\lambda$ が負の場合の軌跡は， $\theta=\pi / 2$ の場合と同様， $\lambda$ が正の場合の軌跡を $y=0$ の $x-z$ 平面を対称面とした面対称図 形となるので，両者をつなぎ合わせれば，磁界が交流振動した場合のアークの往復運動挙動の全体の姿になる. 
ある值以上の振幅の交流磁界でアークを動かそうとした場合，磁界がある值を超えると突然アークが長くなる という現象が起こると理論から予測されたわけであるが，このような挙動が現実のアーク運動で起こりうるか考 えてみる.このようなアーク長の突然な不連続的伸長が起きるためには, アーク電圧の不連続的な増大に対応で きる機能をアーク電源が有していねばならない，実際には，アークが陽極に近づいてから反転して離れていくこ とは起こらず，アークが陽極に近づくと，アークと陽極の間で不安定な電気的回路の短絡が発生し，磁界をさら に強めるとアークは消弧すると予想される.

\section{$5 \cdot 3$ 磁界とアークが $\theta<\pi / 4$ で斜交する場合}

この場合の無次元空間での軌跡は図 6(b)に示されている. $\lambda$ の変化を入れて，実空間に移すための作業はこれ までと同じである. 図 11 は $\theta=\pi / 6$ の場合で, $\lambda$ が変化した時の実空間でのプラズマガスの軌跡（アーク形状）の 変化を描いた. $\lambda$ が変わっても, プラズマガスの 3 次元的な運動は変わらない. また, 陽極点は磁界強度の増加 とともに図に示される方向に移動する， $\theta<\pi / 4$ であれば，図10でみられるような，アークが陽極面と交わる前 に，一度陽極面から上方へ離れてから，陽極面に向かって戻ってくるような振る舞いはしない．このため，陽極 点が不連続的に移動する現象も起こらない. ただし，磁界強度の増加とともにアーク長が伸び，それに伴いアー ク電圧が大きくなるため, アーク電源が許容できる電圧範囲内でしかアークは安定でないと考えられる.

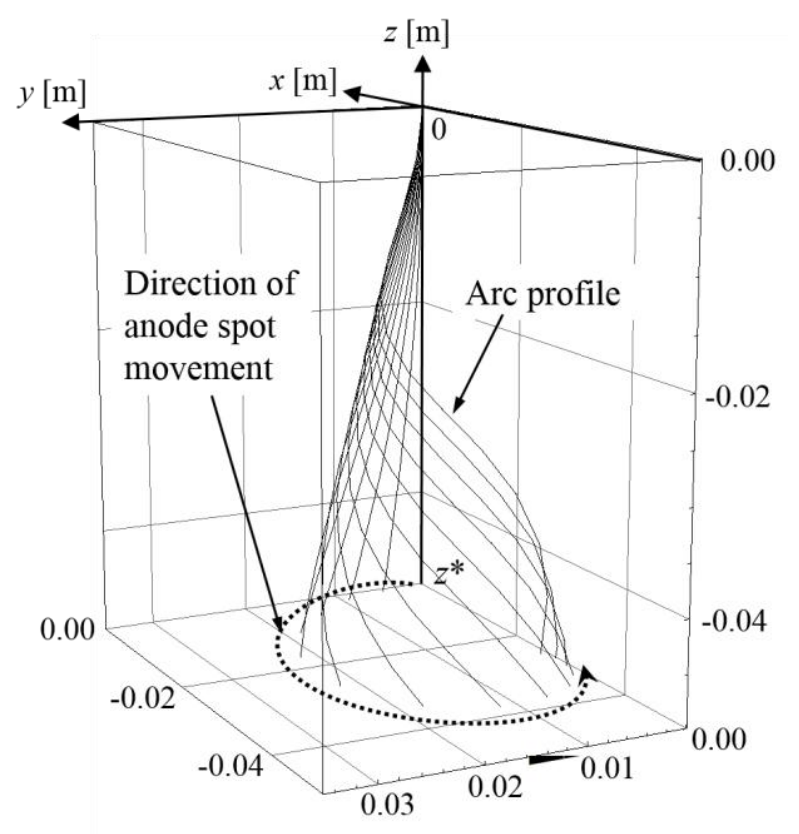

Fig. 11 Arc profiles in oblique magnetic fields $(\theta=\pi / 6)$. As shown in this figure, any discrete jump motion does not occur if $\theta<\pi / 4$.

\section{6. 結 言}

磁気駆動アークの挙動には，アーク電流值や電極間距離，動作ガス流量，トーチノズル径，励磁電流值，外部 磁界作用方向など様々な操作パラメータが関係する. 磁界中のアークの形状を理論的に解析するには, これらの パラメータを含む微分方程式を解かねばならない. 本研究では特性的時間, 特性的長さを導入して時間及び位置 座標をこれらの特性值で除して，無次元化した変数を用いて微分方程式を無次元化することにより，無次元化空 間でのアークの形状が磁界やガス流量，アーク電流值などの条件因子に無関係になることを明らかにした．無次 元化空間でのアーク形状を求めた後で, 特性的時間と特性的長さを用い, 現害の時間, 空間座標に戻してやれば よい，この方法を用いれば，条件因子が異なるごとに異なる微分方程式を解かるばならない困難さがなくなる. 本研究が明らかにした主な結果を以下に示す.

1. 磁気駆動アークの挙動を記述する運動方程式は 3 階常微分方程式となる. 
2. 磁気駆動アークを記述する常微分方程式を特性的時間, 特性的長さを導入して無次元化方程式とすることに より, 無次元化座標空間でのアーク形状は外部磁界の印加角度 $\theta$ にのみ関係し, 磁界強度やアーク電流, そ の他のパラメータには無関係になる.

無次元化空間で記述されるアーク形状を，特性的時間と特性的長さを用いて実空間に逆変換することにより， 磁界強度やアーク電流等のパラメータの影響が現れる. 実空間での磁気駆動アーク挙動の特徴を以下に述べる.

3. 外部磁界がアークに対して直交する $(\theta=\pi / 2)$ 交流磁界の場合, アークは 2 次元的な形状となり, 扇形に広 がる.

4. 直交する磁界で広げられる扇形の幅には最大值が存在し，最大值を与える以上に磁界を強くするとアークは 消弧する.

5. 外部磁界がアークに対し斜交する $(\pi / 2>\theta>0)$ 交流磁界の場合, アークは 3 次元に広がる形状となる. 印 加角度が小さくなるに従い, $Y$ 方向の変位が減少し $X$ 方向変位が増加する.

6. 磁界の印加角度が $\pi / 2>\theta>\pi / 4$ のときは, アークが安定に存在できる最大磁界強度があり, その最大值を超 えるとアークは消弧する.

\section{文献}

Arata, Y. and Maruo, H., Magnetic control of arc plasma and its application for welding, Technology Reports of the Osaka University, Vol. 22 (1972), p. 135.

秋保 良太, 杉本 尚哉, 武田 紘一, 野口 洋介, 三浦 得太郎, 磁気駆動アークによる鋼材熱処理装置の開発, 日本 機械学会論文集 C 編, Vol. 79, No. 806 (2013), pp. 690-703.

Akiho, R., Takeda, K. and Sugimoto, M., Arc motion in an obliquely imposed alternating magnetic field, Jounal of Physics: Conference Series, Vol. 406 (2012), 012036.

Harry, J.E. and Goodwin, D., Surface heat treatment using a plasma torch with a magnetically traversed arc, Proceedings of the 4th International Conference on Advances in Welding Processes, Vol. 181 (1978).

Solonenko, O.P. and Fedorchenko, A.I., Plasma jets in the development of new materials technology (1990), pp. 485- 492. CRC Press.

Takeda, K., Generation of magnetically oscillating plasma arc and its properties, Journal of High Temperature Society, Vol. 16, No. 6 (1990), p. 357.

Toh, T., Tanaka, J., Maruki, Y., Yamamoto, T. and Takeda, K., Magneto hydrodynamic simulation of DC arc plasma under AC magnetic field, ISIJ International, Vol. 45, No. 7 (2005), pp. 947-953.

Tanaka, M., Terasaki, H., Narita, R., Kobayashi, K., Fujii, H. and Ushio, M., Anode heat transfer in TIG arc and its effect on weld penetration, Quarterly Journal of the Japan Welding Society, Vol. 23, No. 3 (2005), pp. 398-404.

Wolfram, S., The mathematic book third edition, Wolfram Research Inc. (1998).

Yamamoto, T., Fundamental study on the arc control for heating over large surface, Doctor Thesis, Akita Prrefectural University (2010).

Yamamoto, T., Takeda, K., Toh, K. and Tanaka, J., Distribution of heat flux transported by a magnetically driven arc, Thin Solid Films, Vol. 515 (2007), pp. 947-953.

\section{References}

Arata, Y. and Maruo, H., Magnetic control of arc plasma and its application for welding, Technology Reports of the Osaka University, Vol. 22 (1972), p. 135.

Akiho, R., Sugimoto, M., Takeda, K., Noguchi, Y. and Miura, T., The development of a heat treatment system using a magnetically driven arc, Transactions of the Japan Society of Mechanical Engineers, Series C, Vol. 79, No. 806 (2013), pp. 690-703 (in Japanese).

Akiho, R., Takeda, K. and Sugimoto, M., Arc motion in an obliquely imposed alternating magnetic field, Jounal of Physics: Conference Series, Vol. 406 (2012), 012036.

Harry, J.E. and Goodwin, D., Surface heat treatment using a plasma torch with a magnetically traversed arc, Proceedings of the 4th International Conference on Advances in Welding Processes, Vol. 181 (1978). 
Solonenko, O.P. and Fedorchenko, A.I., Plasma jets in the development of new materials technology (1990), pp. 485- 492. CRC Press.

Takeda, K., Generation of magnetically oscillating plasma arc and its properties, Journal of High Temperature Society, Vol. 16, No. 6 (1990), p. 357.

Toh, T., Tanaka, J., Maruki, Y., Yamamoto, T. and Takeda, K., Magneto hydrodynamic simulation of DC arc plasma under AC magnetic field, ISIJ International, Vol. 45, No. 7 (2005), pp. 947-953.

Tanaka, M., Terasaki, H., Narita, R., Kobayashi, K., Fujii, H. and Ushio, M., Anode heat transfer in TIG arc and its effect on weld penetration, Quarterly Journal of the Japan Welding Society, Vol. 23, No. 3 (2005), pp. 398-404.

Wolfram, S., The mathematic book third edition, Wolfram Research Inc. (1998).

Yamamoto, T., Fundamental study on the arc control for heating over large surface, Doctor Thesis, Akita Prrefectural University (2010).

Yamamoto, T., Takeda, K., Toh, K. and Tanaka, J., Distribution of heat flux transported by a magnetically driven arc, Thin Solid Films, Vol. 515 (2007), pp. 947-953. 